
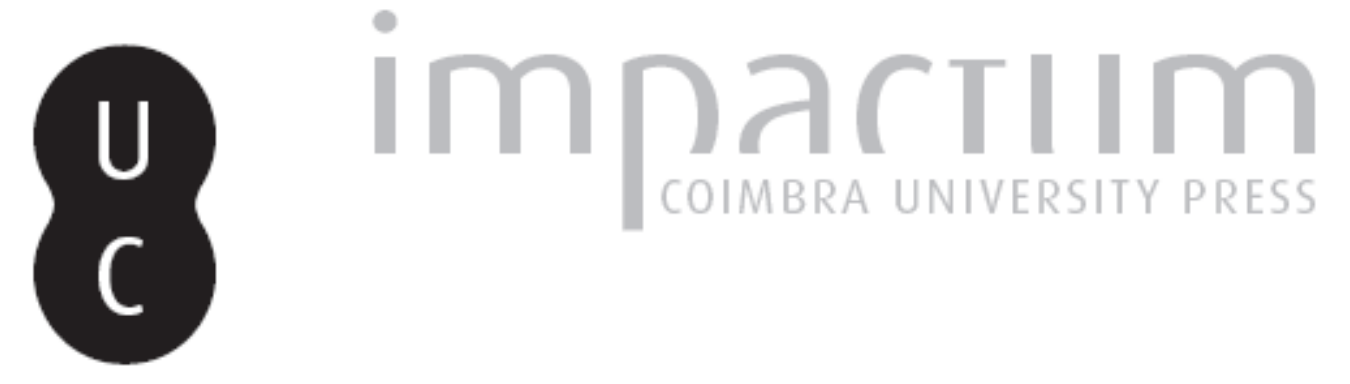

\title{
An introduction to studies in Plato's two-level model
}

Autor(es): $\quad$ Thesleff, Holger

Publicado por: Imprensa da Universidade de Coimbra

URL persistente:

URI:http://hdl.handle.net/10316.2/42273

DOI:

DOl:https://doi.org/10.14195/2183-4105_2_7

Accessed : $\quad$ 26-Apr-2023 13:27:57

A navegação consulta e descarregamento dos títulos inseridos nas Bibliotecas Digitais UC Digitalis, UC Pombalina e UC Impactum, pressupõem a aceitação plena e sem reservas dos Termos e Condições de Uso destas Bibliotecas Digitais, disponíveis em https://digitalis.uc.pt/pt-pt/termos.

Conforme exposto nos referidos Termos e Condições de Uso, o descarregamento de títulos de acesso restrito requer uma licença válida de autorização devendo o utilizador aceder ao(s) documento(s) a partir de um endereço de IP da instituição detentora da supramencionada licença.

Ao utilizador é apenas permitido o descarregamento para uso pessoal, pelo que o emprego do(s) título(s) descarregado(s) para outro fim, designadamente comercial, carece de autorização do respetivo autor ou editor da obra.

Na medida em que todas as obras da UC Digitalis se encontram protegidas pelo Código do Direito de Autor e Direitos Conexos e demais legislação aplicável, toda a cópia, parcial ou total, deste documento, nos casos em que é legalmente admitida, deverá conter ou fazer-se acompanhar por este aviso. 


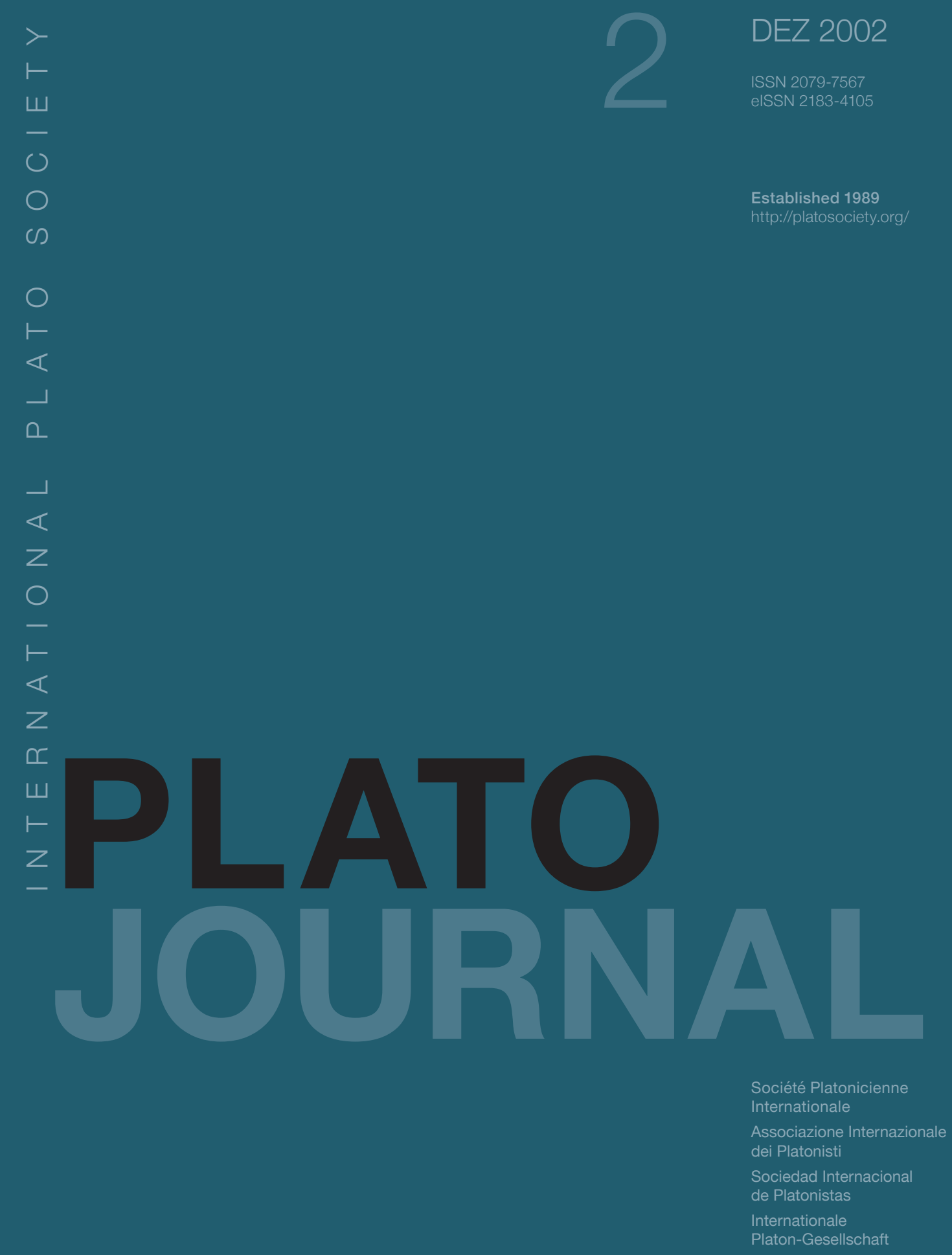




\title{
An Introduction to Studies in Plato's Two-Level Model \\ THESLEFF, Holger, in 2. Plato 2 (2002), \\ [En ligne], January 2002
}

\begin{abstract}
Overall Thesis
The main thesis of the monograph is that the coherence of most issues of Plato's philosophy, and his methods, can be better understood through a single basic vision that I call the 'two-level model' (TLM), found in most dialogues through careful study of Plato's language. Not surprisingly, the pattern is asymmetrical and hierarchical, but I show that it is not limited to a few specific contrasts such as being-becoming or forms-particulars; nor is it distinctly ontological, epistemological, or ethical. It concerns all these and, at the same time, dialectic, psychology, physics, and religion; and it is applicable to dialogue structure and to methodology as well. Plato operates with a vision of one universe whose levels are internally complementary and mutually associative. Neither level exists in isolation from the other: there are not two separate worlds or conflicting dynamic centres, or cosmic opposites.
\end{abstract}

Precedent for Plato's TLM can be found in the Pythagorean table of opposites where one term is primary and dominates the other, and in Eleatic thought where, however, logic demanded a separation of the levels that Plato found problematic. Plato's model is a series of unequal contrasts commonly found in the dialogues, the essentials of which include one-many, same-different, stablechanging, divine-human, soul-body, leading-following, intellect-senses, truth-appearance, knowledge-opinion, defined-undefined. The list could be easily expanded (for instance, man-woman, pure-mixed, sober-drunk). The pairs belong to very different aspects of human experience though the internal, hierarchic relationship of the two terms in each pair is similar, and revealed most easily by the contrast divine-human - metaphorically understood: Plato was not a deeply religious author, but he had a metaphysical and poetical bent.

Whatever is divine has, naturally to Plato, a physical, temporal, and causal priority; and it influences the human level. What is human has a moral and epistemological dependence on the divine; it is oriented towards it. The divine is invisible and the human visible. Yet there is no chôrismos between the levels: they have mutual communication, some distinctions, and a koinonia. They form two sides or aspects of the same universe. In line with the normal world-view of Plato and his contemporaries, the divine, like the sky, is above human and earthly things, above contraries, contradictories, opposites, and all forms of antagonism.

In his application of his model, Plato emphasises the structural relation of the levels in a variety of ways. It is not the theory of forms, or specific contrasts such as being-becoming or intellect-senses, that are primarily characteristic of Plato's thinking, but the TLM as a holistic background vision. One finds several of the pairs in practically every dialogue, though with varying emphases, and I provide a number of examples.

A detailed study of the TLM corroborates three views which have recently gained ground. (1) Plato's thought did not change radically after his Socratic days. (2) The chronological order of the so-called early and middle dialogues is entirely unclear, but new philosophical positions surface in the later dialogues (including the Cratylus and the final version of the Republic) where the part played by Plato's younger associates is often prominent. (3) Since the dialogues are not treatises but dramatic pieces written for specific audiences, they contain allusions, thought-play and thought experiments that can only be interpreted today hypothetically or tentatively.

\section{Bridges.}

Plato was always concerned with bridging the contrasts of the main two levels, and the book discusses many examples, a few of which I mention here. An early clue to the philosopher's orientation was probably given by Socrates' daimonion which warned him about lower-level phenomena but never gave positive advice. Erôs was also an early Socratic image, elaborated by Plato into the philosopher's special power, and in the Symposium into a symbol of the ever-searching philosopher himself. Thus philo-sophia is an intermediate searching, an active orientation towards the upper level. Plato's dialogue technique and the pedimental dialogue structure that he often employs illustrate the climb from a lower level to a higher one by a dialectical search always led by the only real philosopher present. The two-way dialectic (below) is another bridge built successively. The three famous similes in the centre of the Republic, and the simile of the winged chariot in the Phaedrus, point in the same direction. The structure of the utopian state and the tripartite soul (with echoes in Timaeus) reflect yet further aspects of the meeting and combining of the levels, as does the 
construction of the World Soul as an intermediate being in the Timaeus. The most controversial attempt to bridge the levels is the socalled theory of forms in its variations, including the recently ventilated theory of First Principles.

\section{The Theory of Ideas}

As has often been noticed, a core area of the theory of forms concerns forms of a clearly positive value, such as the just, the beautiful, truth in itself (to dikaion ... auto kath' hauto, and similar expressions). Let us call them 'Ideas' with a capital 'I'. It seems that a theory of Ideas took shape before the larger theories of (conceptual) forms and kinds. Both the Phaedo and the Parmenides suggest that such a process took place.

I am far from certain, however, that a theory of Ideas was the historical Socrates' invention, as is sometimes asserted. It is so interwoven with Plato's more theoretical model that one should take the so-called early dialogues as representing Plato's provocative thought experiments with his own orally discussed theories. Aristotle's evidence corroborates the sense one gets from other sources that Socrates never found the standards for a good life that he sought.

Ideas are typically goods conceived as unique upper-level abstractions with varied, always imperfect manifestations on the lower level. They are more or less closely connected to the virtues and, hence, points of orientation for human life. Notions such as entheos, enthousiasmos, theia(i) moira(i), homoiôsis theô( $i$ ) are linked with terms used for the relations between Ideas and their individual manifestations (e.g. parousia, methexis, koinônia). This suggests the divine character of Ideas. However, the interrelations of the Ideas were not the subject of much interest to Plato (except in connection with aretê); they form an undifferentiated whole, though connected to the upper level, as can be seen, for instance, in the pelagos of Diotima and the huperouranios topos in Phaedrus. The motivation for the theory of Ideas is evidently an ethical and epistemological search for the right life in terms of the TLM. This search was a Socratic pursuit, though Plato fitted it into his model.

\section{The Enlarged Theory of Forms}

Given the TLM, the question of immanence versus transcendence of forms makes little sense. All Platonic forms are upper-level entities, and, like Ideas proper, they are present on the concrete level as unity is in plurality, as divinity is in humans, or as soul is in a living body. The logic of the criticism of the forms in Parmenides was not fatal to Plato's own convictions.

The terms eidos and (less commonly) idea for Platonic forms were introduced in oral discussions among Plato's friends, probably via their meaning of 'characteristic shape' (not 'kind') to account for the endless variations of shapes in the physical world. Plato makes a rare pun (Republic, Phaedrus) from the association with eidenai, idein. A section in the methodologically important Meno particularly illustrates the semantic aspect of the term. The ultimately unchanging shape, eidos, of a physical being, a bee, is here equated to the Ideas of virtue; and, like any schêma (cf. also morphê), it is defined by its peras (cf. horos). The term eidos does not refer to a class (though the swarm contains an allusive trap). We need not think, as is traditionally done, that the Meno reflects the theory of noetic forms in-the-making. The dialogue was meant as an Academic contribution to the problem of teachability, and it is full of issues about which the listener or reader is expected to possess some previous information. The theory of Ideas is here taken for granted. 'Form' is a useful term in the search for definitions, but this search is not here Plato's main concern.

A clear slide from Ideas to conceptual forms occurs in the Phaedo in a series of thought experiments instrumental to the main themes of this dialogue. Forms in a general sense, soon called eidê and ideai, come gradually into the picture, associated with the physical opposites discussed earlier in the dialogue. The notoriously obscure logic of the argument as it proceeds is aided by the consideration of the TLM, as I show at some length. Essential qualities of physical beings are regarded as forms through which a being is connected to the upper level. Further, fire and its quality, hot, like soul and its quality, living, are more lasting and dominant than cold snow and the non-living body. Death is not an essential quality of body, and Plato may have found it difficult to imagine a form of death. At any rate, the focus of the theory of forms, like that of Ideas, lies in terms of positive value, and Plato's intuitive vision of the dominance of the upper level is at work the Phaedo. It may well be that Plato is obscure to us because he is deliberately brief, mentioning familiar arguments and problems under debate in the Academy. The Phaedo was not intended as a public manifesto, a demonstration of the soul's immortality directed at ordinary Greek listeners; rather, Plato challenged his listeners with Socrates' everlasting logos; and in this succeeded.

Forms in their general sense may include forms of opposites, of which the physical world is full, though forms do not act or combine as opposites. There also exist forms (though not Ideas) for such notions as similarity and other relations (even for being husband or slave), for plurality and motion. Otherwise forms function like Ideas. However, even in the general theory of forms, the focus is always on positive value, as discussions in Phaedo and Euthyphro exemplify well, for the theory of Ideas is its core. The scope of the theory of forms, reflected in Parmenides, is another problem I examine. Plato did not postulate distinct upper-level forms for all lower-level phenomena that can be grouped or otherwise distinguished.

The divided line, itself an illustration of the TLM (subdivided into four, hence separating Ideas, culminating in to agathon, from forms), suggests that artefacts may have corresponding forms. Early in the Republic, the shapes of good artefacts are said to be changeless, as is the shape (eidos, idea, morphê) of a god, a parallel emphasising that the Greek admiration for variety and innovation is as stupid in theology as it is in the arts. The somewhat playful examples of the shuttle in Cratylus and bed in theRepublic, and the 
absence of artefacts in the lists of Parmenides, hint that Plato hesitatingly accepted the idea that there were (dia)noetic forms for all well-defined objects having a clear shape and function and a rightly given name. Such things, however trivial, are stable and good, that is oriented towards the upper level. This is not a fixed doctrine, but a continuous thought experiment within the TLM.

\section{The Theory of Kinds}

The connotations of the term eidos (and idea) are notoriously unclear. If, as I suggest in the book, the meaning 'characteristic shape' was in the foreground when eidosbegan to be employed for noetic forms, its equally pre-Platonic meaning of 'kind' (species) or class soon became a complication. Plato has no systematic hierarchy of genos-eidos, but he often uses eidos (occasionally idea) loosely as 'aspect', 'type' or 'sort'.

The problem of the interrelations of forms and kinds is likely to have arisen with the dihaeretic method, and especially with the socalled method of division and collection or two-way dialectic (diairesis-sunagôgê). Without going into details in this summary, I suggest that the distinction between forms and kinds remained unclear to Plato. This may be an example of the well-known phenomenon that semantic connotations contribute to a confusion in thought. Ultimately, it is a question of the degree of metaphysics involved. Forms belong in principle to Plato's higher level, kinds concern groupings on the lower level. With the gradual shift of interest of Plato's friends in the Academy, kinds (later universals) came into the foreground.

On the assumption that Plato and his nearest circle were unable (or unwilling) to make a sharp distinction between (dia)noetic forms and sensible kinds, the unclear terminology in fact contributes to a bridging of the contrast between the levels of reality. This is manifest in the theories of the mixing of kinds and forms, respectively, which occupies large portions of Parmenides, Sophist, Politicus, and Philebus. I discuss at length what I must mention only briefly here, the megista genê.

\section{The Greatest Kinds}

In the Sophist, the Eleatic Stranger tries to solve the Parmenidean problem of hen-polla and being-non-being, and to clear up the mass of things (including doxa) behind which the sophist tends to hide, by showing that certain forms that appear to be opposites can in fact mix (sumplokê, koinônein etc.) in various ways. His examples are the greatest kinds that exist, termed genê and eidê and even ideai: being (ousia, to on); and two pairs of apparent opposites: rest and motion (stasis-kinêsis) and sameness and otherness (tauton-thateron), the latter particularly useful in coping with non-being; a third pair, unity and plurality (well known from the Parmenides) figure in the background. The greatest kinds cover all that is; they are, of course, forms in the sense of (dia)noetic abstractions, though they are certainly not Ideas. But why call them kinds?

I address this intricate question, as have many others, by assuming that the Sophist represents a new step away from the earlier theories of Ideas and forms, under the influence of Eleatic criticism. But I also show, through Plato's use of language, first, that the TLM gives a clue to the argument; second, that the previous theories are not discarded; and, third, that the new step was partly motivated by the indistinct terminology of 'forms' and 'kinds'. I can here only sketch the book's argument.

One might call the megista genê 'categories' and see them as a lateral projection of the TLM. Being (in a general sense) gives the frame. The rest of the categories consist of pairs that are in fact not polar opposites, but asymmetrically related just as Plato's two main levels are: rest, sameness and unity are typical of the upper divine level; motion (or change), otherness and plurality are typical of the human level. Yet both belong together in Plato's universe. The categories are the superlative kinds in the sense of having the largest scope and extending over both levels, but not in the sense of being highest in any hierarchy of forms.

The categories are already mentioned in Parmenides, indeed as Socrates's own invention. Though there were probably Eleatic impulses to the development of this theory, I note clear signs of Plato having associated it with the activities of the soul and its search for knowledge. In the Theaetetus, the first dialogue prefiguring the Sophist andPoliticus, we find in a much-discussed passage an illustration of how Plato's thoughts ran. Having criticised at length various theories of flux versus standstill, Socrates extracts from Theaetetus the suggestion that the human soul makes use of being, sameness and otherness (and probably rest and motion), and also hen and number, when it considers by itself the community of all (ta koina peri pantôn) and the opposites in our world. The categories are thus inherent in the human soul. We are reminded of theanamnêsis experiment in the Meno and its reflections in the Phaedo with their references to similarity and mathematical concepts. In the Phaedrus, the brief proof of the soul's immortality contains elements that, on closer inspection, connect the soul to the ontological categories. There are glimpses of them in the psychology of the Republic, but the clearest indication of this connection is the construction of the World Soul in Timaeus. We have here ousia and tauton-thateron and kinêsis (stasis being implied in the system); mathematical concepts are made inherent in the soul; and the contrasting pair of indivisible-divisible, which is taken from the dihaeretic method, can also be said to stand for the familiar unity-plurality contrast. Thus the World Soul becomes an intermediate being whose function, through its inherent categories and by the principle of like likes like, is to transfer information and activity between the two levels of the TLM. Passages from Phaedo, Phaedrus, and others from the Timaeus add further points to this argument.

\section{The Theory of First Principles}

In the Philebus, the categories are gradually being replaced by a Pythagoreanizing metaphysical contrast, between limit and limitless (peras and apeiron), which is used to explain the mixture of a good life. As has been often argued, we are now close to what our 
sources, beginning with Aristotle, refer to as Plato's orally expressed opinions (agrapha dogmata).

To reconsider this theory of one (hen) versus undefined twoness (aoristos duas, which includes the great-and-small), and the recent, partly heated, discussion about it, would require a large study of its own. Saying very briefly here what I argue in the book, the sources imply that Plato, late in his life, made a new thought experiment in the Pythagoreanizing direction. He extrapolated from the theories of categories and of peras-apeiron in the direction of mathematical metaphysics (and again laterally), a contrasting pair of First Principles. The one stands for his upper level in its entirety, the undefined twoness stands for the lower level, but the levels are still interactive. The idea-numbers, which Aristotle emphasizes, fit into this picture. Although the one approaches to the good, and twoness now extends to the realm of the receptacle of theTimaeus, or what Aristotle termed hulê (cf. Plotinus' interpretation of Platonism), Plato never gave up his vision of a universal koinônia.

HOLGER THESLEFF 